\title{
REHUJEN JALOSTUSARVOLASKELMISTA.
}

\author{
AntTi MäKI. \\ Yliopiston maanviljelystaloudellinen laitos, Helsinki.
}

Saapunut 4. IV. 1945.

Rehuviljavaltaisessa maatalousvyöhykkeessä, johon maamme muiden Pohjoismaiden kanssa kuuluu, on suurin osa satotuloksesta jalostettava myyntikelpoisiksi tuotteiksi hyötykarjan välityksellä. Maamme rehusato, oljet ja laitumien tuotto mukaan luettuna, on n. $80-85 \%$ kokonaissadosta rehuyksiköiksi laskettuna. Huomattavan suuri osa tästä rehumäärästä on ns. absoluuttista karjanrehua, jonka käyttäminen suoraan ihmisravinnoksi tai muihin tarkoituksiin ei tule kysymykseen. Vaikka kasvinviljelys olisi suunnattu pääasiassa ihmisravinnoksi kelpaavien tuotteiden tuottamiseen, saadaan sivutuotteina aina myös absoluuttisia rehuja, joiden jalostaminen on mahdollista vain kotieläinten välityksellä. Kun hyötykarjan ja erityisesti nautakarjan pidon taloudellisena päätarkoituksena on pidettävä niiden satotuotteiden jalostamista, jotka eivät sellaisenaan ole myyntikelpoisia tai joita ei kuljetuskustannusten tähden kannata lähettää markkinoille, on sillä hinnalla, joka karjan välityksellä jalostetuista rehuista saadaan, ratkaiseva merkitys maatalouden kannattavuudelle. Rehujen jalostushintaa ei siten ole pidettävä ainoastaan karjatalouden kannattavuuden mittana, vaan sitä voidaan tietyin edellytyksin pitää koko maatalouden antaman taloustuloksen osoittajana. Muutos rehuyksikön jalostushinnassa merkitsee koko maataloudelle huomattavasti enemmän kuin yhtä suuri muutos viljakilon hinnassa. Kun karjatalouden kannattavuuden määrittäminen itsenäisenä maatalouden osana tuottaa erittäin suuria vaikeuksia etupäässä rehujen hinnoittamiseen nähden, on siitä yleensä luovuttu ja ryhdytty käyttämään karjatalouden kohdalla ns. tasoitusmenetelmää, jossa taloustulos ilmaistaan rehuista saadun hinnan muodossa.

Rehujen jalostusarvon laskutapaa on EHRENBERGin (6, s. 49-59) mukaan käytetty jo lähes 80 vuoden ajan. Menetelmä on kehittynyt 
yhdessä ruokintaopin ja maanviljelyskemian edistymisen kanssa, ja se on saanut suuremman merkityksen vasta sen jälkeen kun rehujen tuotantoarvon mittaaminen yhdellä yksiköllä on tullut käytäntöön. Erityisesti Pohjoismaissa on kiinnitetty huomiota jalostusarvolaskelmiin ja niissä käytettävien menetelmien kehittämiseen. Ensi sijalla on tässä yhteydessä mainittava NANNESON, joka on käsitellyt ja kehittänyt jalostusarvokysymystä lukuisissa julkaisuissaan yli kolmen vuosikymmenen aikana. Jalostusarvolaskelmaa on käytetty myös Ruotsin ja Tanskan maatalouden kannattavuustutkimuksissa sekä kirjanpitovuodesta 1933-34 alkaen myös Suomen maatalouden kannattavuustutkimuksissa. Lisäksi on jalostusarvolaskelmia suoritettu maassamme valtion koulutiloilta ja myös eräiltä yksityistiloilta. Jalostusarvolaskelma oli myös sisällytetty tarkastuskirjanpitoon vuosina 1930 - 44. Laskelman suorituksen helpottamiseksi käytettiin tarkastuskirjanpidossa kaavamaista menetelmää, jossa karjatalouden peruskustannus (vakinaiset kustannukset) ilmaistiin vakioluvuilla. Vuonna 1944 laskelma poistettiin käytännöstä ja korvattiin luontoistuloksia koskevalla laskelmalla, josta saatuja arvoja voidaan käyttää myös perusteellisempien laskelmien lähtökohtana. Karjatalouden kannattavuuskysymyksiä ja jalostusarvolaskelmaan liittyvien kustannuserien suuruutta on erityisesti tutkittu L.S.K:n (Länsi-Suomen Karjanjalostusyhdistyksen) kirjanpitotoimistossa vuodesta 1929 alkaen $(1,2,3)$. Julkisuuteen saatetuista kirjanpitotuloksista on vielä mainittava Hämeen-Satakunnan maanviljelysseuran kirjanpitotoimiston julkaisut, joissa käsitellään myös karjatalouden kannattavuuskysymyksiä jalostusarvolaskelman pohjalla (19).

Jalostusarvolaskelmiin ja niiden käyttöön liittyy useita kohtia, jotka kaipaavat lisäselvitystä, ennenkuin laskelmien tuloksia voidaan soveltaa käytäntöön siinä laajuudessa kuin laskelman keskeinen asema ja merkitys edellyttäisivät. Erityisesti olisi menettelytavoissa pyrittävä nykyistä suurempaan yhtenäisyyteen, jotta tulosten keskinäinen vertailu kävisi mahdolliseksi. Seuraavassa käsitellään lähinnä teoreettiselta kannalta eräitä jalostusarvolaskelmiin ja niiden tulosten käyttöön liittyviä kysymyksiä.

\section{Terminologiaa.}

Kun jalostusarvolaskelma on ollut käytännössä suhteellisen lyhyen ajan, on ymmärrettävää, ettei terminologia tällä alalla ole vielä 
vakiintunut. Saksankielisten termien Verwertungswert tai Verwertungspreis ja Veredlungswert sekä ruotsinkielisen förädlingsvärde vastineena on suomenkielessä käytetty oppisanoja jalostusarvo tai jalostushinta, hyväksikäyttöarvo ja korvaushinta, joista jälkimmäinen on viime vuosina mm. tarkastuskirjanpidon välityksellä levinnyt laajimpaan käyttöön. Terminologian vakiintumattomuutta osoittaa, että samassa julkaisussa voi nähdä käytetyn kolmea eri termiä rinnakkain (7). Suomalaiseen terminologiaan lienee vaikuttanut tanskankielinen Udnyttelsespris, jonka ohella on käytetty termejä Bruttobetaling ja Nettobetaling (23). Korvaushinta-termiä ei tämän kirjoittaja ole voinut pitää onnistuneena, vaikka on sitä itsekin aikaisemmin käyttänyt $(12,13)$. Tämä kannanotto perustuu lähinnä siihen, että korvaushinta on soveltumaton rehujen arvon mitan ilmaisuksi, koska se edellyttää kysymystä tarkasteltavan aina karjatalouden kannalta. "Rehujen korvaushinta» ei ilman erikoisselvityksiä voi merkitä sitä käsitettä, jota sanoilla tarkoitetaan ilmaista. Lisäksi termi sekaantuu toiseen, eri käsitettä merkitsevään sanaan, jota ruotsinkielessä vastaa ersättningsvärde ja jonka vastineena on suomenkielessä käytetty »korvikearvoa». Epäonnistuneesta oppisanasta on myös johtunut, että »korvaushinta" on tullut virheellisesti käännetyksi vieraille kielille. Sen saksalaisina vastineina on käytetty $\mathrm{mm}$. sanoja "Entschädigungspreis» ja "Ersatzpreis», joita on pidettävä täysin harhaan johtavina. Kun suomenkielessä on käytettävissä ulkomaisia oppisanoja vastaava jalostusarvo tai jalostushinta, jotka soveltuvat kaikkiin käsitteen edellyttämiin tarkoituksiin, olisi niiden käyttö vakiinnutettava epäonnistuneen "korvaushinnan» asemesta.

Vaikka arvo ja hinta ovat kansantaloudessa selvästi toisistaan eroavia käsitteitä, tuottaa näiden sanojen johdonmukainen erimerkityksellinen käyttäminen useissa tapauksissa vaikeuksia. Kun omaisuusosien arvolla (taloudellisessa mielessä) tarkoitetaan niiden arvioitua hintaa, jää riippumaan ajatusyhteydestä, kumpaa sanaa olisi kulloinkin käytettävä. Näin ollen voidaan jalostusarvoa käyttää tuloksen mittana, joka tuotantotoiminnassa arvioidaan hyödykkeistä saatavan, kun taas jalostushinta soveltuu käytettäväksi tarkoitettaessa todella saatua tulosta, joka on hintaan verrattavissa.

\section{Jalostusarvon laskutavoista.}

Nautakarjalle käytetyn rehun jalostusarvo eli -hinta saadaan vähentämällä karjan tuotosta muut tuotantokustannukset paitsi nii- 
den rehujen arvoa, joiden jalostusarvo halutaan saada lasketuksi. Karjatalouden kustannukset voidaan tarkoituksenmukaisesti jakaa kahteen osaan, peruskustannukseen ja rehukustannukseen, jolloin edelliseen luetaan kaikki muut kustannukset paitsi rehujen arvoa. Peruskustannus sisältää useita eri kustannusosia, jotka voidaan AnNilan (2, s. 88) mukaan ryhmitellä alla olevan asetelman mukaisesti. Kun seuraavassa tullaan käsittelemään myös eräiden peruskustannuksen osien suuruussuhteita, esitetään asetelmassa myös eri kustannusten prosenttinen osuus peruskustannuksesta ja karjatalouden tuotosta ANNilan esittämien keskiarvolukujen perusteella laskettuna.

\begin{tabular}{|c|c|c|c|c|c|c|}
\hline Kustannuserä & $\begin{array}{r}\text { Lehmá } \\
\text { vuo }\end{array}$ & $\begin{array}{l}\text { kohden } \\
\text { ssa mk }\end{array}$ & $\begin{array}{r}\% \mathrm{pe} \\
\mathrm{n},\end{array}$ & $\begin{array}{l}\text { iskustan- } \\
\text { sesta }\end{array}$ & $\begin{array}{l}\% \text { lyp } \\
\text { jan tr }\end{array}$ & $\begin{array}{l}\text { sykar- } \\
\text { otosta }\end{array}$ \\
\hline Työkustannus & & & & & & \\
\hline Ihmistyökustannus . . . . . . . . & 562 & & 40.00 & & 15.60 & \\
\hline Hevostyökustannus $\quad \ldots \ldots \ldots$ & 8 & 570 & 0.59 & 40.59 & 0.23 & 15.83 \\
\hline Sekalaiskustannus & & & & & & \\
\hline Sonninpitokustannus ....... & 79 & & 5.63 & & 2.19 & \\
\hline Kuivikekustannus $\ldots \ldots \ldots \ldots$ & 50 & & 3.56 & & 1.39 & \\
\hline Polttopuukustannus $\ldots \ldots \ldots$ & 22 & & 1.57 & & 0.61 & \\
\hline Valo- ja voimakustannus .... & 14 & & 1.00 & & 0.39 & \\
\hline Erilliset rahamenot & 68 & & 4.84 & & 1.89 & \\
\hline Yleiskustannus $\quad \ldots \ldots \ldots \ldots$ & 117 & 350 & 8.33 & 24.93 & 3.25 & 9.72 \\
\hline Pääomakustannus & & & & & & \\
\hline Kalustokustannus & 15 & & 1.07 & & 0.42 & \\
\hline Eläinkustannus $\ldots \ldots \ldots \ldots$. & 339 & & 24.15 & & 9.42 & \\
\hline Rakennuskustannus $\ldots \ldots \ldots$ & 130 & 484 & 9.26 & 34.48 & 3.61 & 13.45 \\
\hline Yhteensä & & 1404 & & 100.00 & & 39.00 \\
\hline
\end{tabular}

Peruskustannus on L.S.K:n kirjanpitotoimiston kirjanpitotiloilta saadun aineiston perusteella vuosilta 1929-36 ollut keskimäärin $39 \%$ lypsykarjan tuotosta (2, s. 88). Tämän suhdeluvun vaihtelulaajuus on ollut 32.0-50.2. Hämeen-Satakunnan maanviljelysseuran kirjanpitotoimiston kirjanpitotiloilla on peruskustannus vuosina 1927 - 32 ollut 50.0 - $68.7 \%$ tuotosta, ja maataloushallituksen kirjanpitotiloilla vuosina 1933 - 39 vastaava luku on ollut $29.0-33.6 \%$. Edellä esitetyt luvut eivät ole toisiinsa verrattavia, koska kustannuserien ja tuóton laskemisessa on käytetty varsinkin työkustannuksen ja karjan uudistuskustannuksen kohdalla toisistaan poikkeavia laskutapoja ja koska maataloushallituksessa suoritetut laskelmat koskevat nautakarjaa kokonaisuudessaan, eivätkä ainoastaan lypsykarjaa. 
Jalostusarvolaskelma voidaan laatia hyvin monella eri tavalla riippuen siitä, mikä asetetaan laskelman tarkoitukseksi, mitä tuottoja kustannuseriä laskelmaan sisällytetään ja miten ne käsitellään. Erilaisia menetelmiä käyttäen saadaan myös erilaiset lopputulokset, joita voidaan verrata ainoastaan vastaavalla laskumenetelmällä saatuihin tuloksiin ja käyttää ainoastaan laskumenetelmän edellyttämiin tarkoituksiin. Tässä suhteessa on usein havaittavissa käsitteiden sekaannusta.

Jalostusarvolaskelmassa voidaan ensiksikin erottaa kaksi eri päätyyppiä riippuen siitä, otetaanko laskelman kustannuspuolelle kaikki edellä luetellut, peruskustannukseen kuuluvat kustannuserät vai ainoastaan karjatalouden välittömät eli suoranaiset kustannukset. Jälkimmäisessä tapauksessa jäävät ns. välilliset kustannukset laskelman ulkopuolelle. Niihin luetaan johtotyön arvo, rakennusten kuoletus, kunnossapito ja vakuutus, karjatalouden osuus maatalouden yleiskustannuksista sekä karjatalouteen sidottujen pääomien korkovaatimus. Korkovaatimus on maatalouskirjanpidossa sikäli erikoisasemassa, ettei sitä lueta maatalouden liikekustannukseen, vaan taloustuloksen mittana käytetään yleisesti pääomista saatua korkoa (puhdasta tuottoa). Muiden karjatalouden välillisten kustannusten taas voidaan katsoa rasittavan maataloutta riippumatta siitä, miten karjatalous on järjestetty ja millainen on karjatalouden voimaperäisyysaste.

Kun jalostusarvolaskelman kustannuksiin luetaan peruskustannus kokonaisuudessaan, saadaan tulokseksi nettojalostusarvo. Milloin välilliset kustannukset jätetään laskelman ulkopuolelle, tuloksena on bruttojalostusarvo. NANnESon (16, s. 106) suosittelee käytettäväksi ensi sijassa jälkimmäistä jalostusarvon laskutapaa. Myös Pohjoismaiden Maataloustutkijan Yhdistyksen maanviljelystaloudellisen jaoston asettama komitea pitää bruttojalostusarvoa tarkoitukseen paremmin soveltuvana (4, s. 13-14). Ruotsin maatalouden kannattavuustutkimuksissa on esitetty tilivuodesta 1924 -25 lähtien bruttojalostusarvo ja Tanskan maatalouden kannattavuustutkimuksissa vuodesta 1922 - 23 lähtien sekä brutto- että nettojalostusarvo. Suomessa on yleensä käytetty nettojalostusarvon laskutapaa.

Brutto- ja nettojalostusarvoilla on huomattava teoreettinen ja käytännöllinen ero. Samoin on eroa näiden tulosten käyttömahdollisuudessa. Annilan (2) julkaisemien kirjanpitotulosten perusteella saadaan välillisten kustannusten arvoksi (vuosina 1929-36) n. $368 \mathrm{mk}$ lypsylehmää kohden eli $26.2 \%$ peruskustannuksesta ja $10.2 \%$ lypsy- 
karjan tuotosta. Tällöin on välillisiin kustannuksiin luettu paitsi yleiskustannusta, johon sisältyy myös johtotyön arvo, rakennuskustannukset sekä kalusto- ja eläinpääomien korot. Hämeen-Satakunnan maanviljelysseuran kirjanpitotoimistossa suoritetuissa laskelmissa vuosilta 1927 - 32 ovat johtotyön arvo, rakennus- ja korkokustannukset olleet 458 - 513 mk lypsylehmää kohden eli $16.1-20 \%$ peruskustannuksesta ja $8.1-12.3 \%$ lypsykarjan tuotosta (19, s. 100-101). Maataloushallituksen kirjanpitotiloilla ovat rakennus- ja yleiskustannukset sekä eläinpääoman korot vuosina 1933-39 olleet $330-375 \mathrm{mk}$ nautayksikköä kohden eli $29-33.8 \%$ peruskustannuksesta ja $9.1-$ $10.9 \%$ nautakarjan tuotosta. Vaikka nämä summat eivät ole markkoinakaan lausuttuina täysin toisiinsa verrattavissa, ne osoittavat kuitenkin, mitä suuruusluokkaa on ns. välillisten kustannusten vaikutus rehujen jalostusarvoon. Kun perusrehun määrä on esim. L.S.K:n kirjanpitotiloilla keskimäärin ollut n. 1675 ry lypsylehmää kohden vuodessa, merkitsee välillisten kustannusten osuus n. 22 pennin erää ry:ä kohden. Yksityisillä tiloilla voi välillisten kustannusten vaikutus olla huomattavasti suurempi ja nousta julkaistujen tulosten mukaan jopa 43 penniin perusrehun ry:ä kohden. Paitsi sitä, ettei brutto- ja nettojalostusarvoja tietenkään voida pitää toisiinsa rinnastettavina suureina, on näiden laskutapojen välisellä erolla tärkeä merkitys arvosteltaessa karjatalouden ja koko maatalouden kannattavuuskysymyksiä jalostusarvolaskelmien tulosten perusteella, kuten myöhemmästä esityksestä ilmenee. Merkityksestään huolimatta on kysymyksen lähempi selvittely sivuutettu asiaa koskevissa julkaisuissa tai tyydytty vain lyhyeen mainintaan $(16, \mathrm{~s}, 106 ; 17$, s. 116 ; 4, s. 13-14). Jonkin verran laajemmat perustelut esitetään Ruotsin maatalouden kannattavuustutkimuksissa vuodelta 1924-25 (21, XI, s. 49).

Nautakarjaa koskeva jalostusarvolaskelma voidaan laatia joko koko karjaa tai ainoastaan lypsykarjaa varten. Jälkimmäisessä tapauksessa on laskelmassa otettava huomioon myös nautakarjan sisäiset suoritukset, ts. laskettava lypsykarjan tuotoksi syntyneiden vasikoiden arvo ja vasikoille käytetyn maidon arvo sekä kustannuksiksi lypsykarjan uudistuskustannus, jolla tarkoitetaan lehmän hankintaja poistoarvon välistä hinnaneroa vuotta kohden laskettuna (2, s. 23). Molempia laskutapoja voidaan käyttää, mutta laskelmien tulokset eivät ole toisiinsa rinnastettavia. Milloin rehujen jalostusarvo lasketaan eri rehuille niiden laadun edellyttämässä suhteessa, ei ole tarkoituksenmukaista laskea jalostushintaa yhteisesti koko nautakarjaa 
varten, koska lypsykarjan ja nuoren karjan vaatimukset rehujen väkevyyteen ja valkuaismäärään katsoen ovat erilaiset. Toisaalta on koko nautakarjaa koskevan laskelman etuna pidettävä tulosten luotettavuuden kohoamista sen johdosta, että sisäisten suoritusten arviointi tulee tarpeettomaksi.

Kolmantena ja ehkä tärkeimpänä tekijänä jalostusarvolaskelman rakenteeseen ja suoritustapaan vaikuttaa, mihinkä osaan rehumäärästä laskelma ulotetaan ja missä suhteessa saatu jalostushinta jaetaan eri rehuille. Laskelma voi koskea kaikkia rehuja, omasta taloudesta tuotettuja rehuja tai ainoastaan sellaisia omasta taloudesta saatuja rehuja, joilla ei voida katsoa olevan jalostamattomina yleistä markkina-arvoa. Jälkimmäiseen ryhmään kuuluvia rehuja voidaan nimittää yhteisellä nimellä perusrehuksi, ja siihen luetaan tavallisesti korsirehut, tuorerehut ja laidunrehu. Ensimmäisellä vaihtoehdolla, jalostushinnan laskemisella kaikkien karjalle käytettyjen rehujen osalta, on tuskin merkitystä silloin, kun jalostushinta lasketaan ottamatta huomioon erilaisten rehujen kuiva-aine- ja valkuaismääriä. Sitä vastoin laskettaessa jalostushinta edellä mainittujen seikkojen perusteella on lähtökohtana pidettävä koko rehuannoksen keskimääräistä jalostushintaa ry:ä kohden laskettuna. Eri rehujen hinta on silloin keskimääräisen ry-hinnan ylä- tai alapuolella riippuen siitä, tarvitsevatko ne täydennyksekseen ostoväkirehuja vai voidaanko niillä korvata ostorehujen käyttöä. Ostorehujen aiheuttama kustannus tulee siten jaetuksi eri rehuille siinä suhteessa kuin ne tarvitsevat väkirehutäydennystä. Lopputuloksena tässäkin tapauksessa on kotoisten rehujen jalostushinnan selvittäminen, jota on pidettävä laskelman päätarkoituksena. Yleisimmin on jalostushinta laskettu ainoastaan ns. perusrehulle, jolloin kotoisten väkirehujen arvo niiden markkinahinnan perusteella on luettu karjatalouden kustannuksiin. Hämeen-Satakunnan maanviljelysseuran kirjanpitotoimistossa on jalostushinta laskettu myös omasta taloudesta tuotetulle viljalle (19, s. 98-99), joten laskelma koskee kotoista rehua kokonaisuudessaan. Käytettäessä yksinkertaista, ainoastaan ry-määrään perustuvaa jalostusarvolaskelmaa riippuu jalostushinnan ja rehuviljan markkinahinnan välisestä suhteesta, kumpaa menetelmää on pidettävä suositeltavampana. Jos rehuviljalla on varma menekki ja sen hinta on huomattavasti yläpuolella jalostushinnan, voidaan jalostushinnasta saada harhaanjohtava kuva k.o. viljelyskasvin kannattavuusedellytyksistä. Päinvastaisessa tapauksessa olisi pidettävä virheellisenä hinnoittaa rehuvilja halvemmaksi kuin mitä karja maksaa muista, 
laadultaan vähäarvoisemmista rehuista. Kun kuitenkaan rehuviljalla ei yleensä voida katsoa olevan sellaista hintaa, joka suhteellisen vähäisistä myyntieristä voidaan saada, ja kun toisaalta jalostusarvolaskelma sitä paremmin vastaa tarkoitustaan, mitä vähemmän siihen jää harkinnasta riippuvia tekijöitä ja mitä suurempi osa karjatalouden tuotosta voidaan käyttää jalostushinnaksi, on pyrittävä siihen, että jalostushinta yleensä laskettaisiin kaikille kotoisille rehuille. Ne epäkohdat, jotka liittyvät ry-määrään perustuvaan laskelmaan, voidaan välttää jaoittelemalla eri rehujen jalostushinta niiden tuotantoarvon mukaan siinä määrin kuin tähänastisten tutkimustulosten perusteella on mahdollista. Silloin arvokkaimmat rehut tulevat saamaan jalostushinnan, joka on lähellä samojen rehujen keskimääräistä myyntihintaa. Tätä tietä voidaan myös päästä tyydyttävään tulokseen arvosteltaessa jalostushintojen perusteella eri viljelyskasvien kannattavuusmahdollisuuksia.

Kotoisten rehujen jalostushinta voi tulla jaetuksi eri rehuille hyvin monella eri tavalla, joista saadut tulokset tietenkin poikkeavat toisistaan. Jalostushintaa jaettaessa on ensiksi ratkaistava kysymys laidunrehun hinnan määrittämisestä. Tavallisesti laidunry:lle lasketaan joko yhtä korkea jalostushinta kuin muillekin rehuille tai laidunry:n arvo lasketaan puoleksi muiden rehujen vastaavasta arvosta. Edellinen menettelytapa on omaksuttu mm. tarkastuskirjanpidossa suoritetuissa jalostushintalaskelmissa. L.S.K:ssa ja maataloushallituksessa suoritetuissa laskelmissa on käytetty osaksi kumpaakin menetelmää. Hämeen-Satakunnan maanviljelysseuran kirjanpitotoimisto on käyttänyt jälkimmäistä tapaa. Jos edellisessä vaihtoehdossa lisäksi lasketaan eri rehujen suhteellinen jalostusarvo niiden väkevyyden ja valkuaismäärän perusteella, kohoaa laidunry:n arvo laatunsa tähden varsin korkeaksi. Kuitenkin on huomattava, että laidunrehua voidaan käyttää ainoastaan kesällä, joten voidaan katsoa, että laidunrehun korkeampi laatu voi vain sangen vähäisessä määrin korvata talvirehun puutteellisuuksia. Sen tähden ei voida katsoa laidunrehun hinnan riippuvan sen laadusta samalla tavoin kuin talvirehuissa, koska täten jouduttaisiin siihen, että laidunry:n hinta olisi korkeampi kuin kotoisten talvirehujen keskimääräinen jalostushinta. Tästä seuraa, ettei laidunrehuun tarkoituksenmukaisuussyillä voida soveltaa väkevyyteen ja valkuaismäärään perustuvaa jalostusarvon laskutapaa, vaan laidunrehu voitaisiin enintään hinnoittaa keskimääräisen ry-hinnan mukaan. Asialla on kuitenkin toinen puolensa sen johdosta, että laidunrehun tuotantokustannukset ry:ä kohden ovat paljon hal- 
vemmat kuin muiden rehujen. Keskimäärin katsoen voidaan laidunrehun arvioida tulevan tuotetuksi noin puolella muiden rehujen tuotuotantokustannuksista. Mikäli tuotantokustannukset tunnetaan, voitaisiin niitä käyttää jalostusarvolaskelmassa laidunry:n hinnan määrittämisessä. Samalla olisi kuitenkin pyrittävä siihen, että taloustulos ilmenisi myös laidunry:n hinnan vaihteluna. Oikeaan osuvalta tuntuisi laskutapa, jossa laidunry:n hinta olisi samassa suhteessa muiden rehuyksiköiden jalostushintaan kuin laidunry:n tuotantokustannus on talvirehujen keskimääräiseen tuotantokustannukseen (12). Yksityiskohtaisten kustannuslaskelmien puuttuessa voidaan lähtökohtana pitää Suomessa käytettyä tapaa hinnoittaa laidunrehuyksikkö puoleksi keskimääräisestä ry:n hinnasta.

Jos laidunrehun arvo määritetään edellä esitetyn mukaisesti, on vielä erilaisia vaihtoehtoja siinä suhteessa, miten laidunry:n hintaa laskelmassa käsitellään. Laidunry:n hinta voidaan laskea puoleksi kaikkien rehuyksiköiden jalostushinnasta tai puoleksi talvirehujen jalostushinnasta $(18$, s. 90). Edellisessä tapauksessa laidunry tulee hinnoitetuksi halvempaan hintaan kuin jälkimmäisessä vaihtoehdossa. Laidunry:n hinta ei siinä ole kiinteässä suhteessa talvirehujen hintaan, vaan hinta riippuu laidunrehun määrän suhteesta muiden rehujen määrään. Hämeen-Satakunnan maanviljelysseuran kirjanpitotoimistossa on käytetty tätä menetelmää. Kun kummassakin vaihtoehdossa jalostushinta voidaan laskea keskimäärin kaikille rehuille, kotoisille rehuille tai perusrehulle, tulee laidunry:n hinta hieman erilaiseksi kussakin eri tapauksessa. Yleensä voitaneen pitää oikeutettuna Pinkalan (18) suosittelemaa tapaa laskea laidunrehuyksikön hinta puoleksi kotoisten rehujen keskimääräisestä ry:n jalostushinnasta.

Kotoisille talvirehuille jäävä jalostushinta voidaan edelleen jakaa eri rehuille useita eri perusteita käyttäen. Jättäen kokonaan huomioon ottamatta vanhimmat, ennen rehuyksikön ja tärkkelysarvoyksikön kehittämistä käytetyt menettelytavat, joita mm. EHRENBERG (6) selostaa, on nykyisin käytännössä kolme toisistaan poikkeavaa menetelmää. Jalostusarvo määritetään rehujen tuotanto-ominaisuuksien perusteella, jolloin voidaan ottaa huomioon:

1) rehuyksikköarvo,

2) rehuyksikköarvo ja kuiva-ainemäärä,

3) rehuyksikköarvo, kuiva-ainemäärä ja valkuaismäärä.

Muita rehujen tuotantoarvoon vaikuttavia tekijöitä tuskin voi- 
daan toista1seksi ottaa huomioon taloudellisissa laskelmissa. Lisäselvitystä kaipaisi tässä suhteessa esim. kysymys eri rehujen sisältämän vesimäärän vaikutuksesta rehujen tuotantoarvoon, työ-, kuljetus- ja säilytyskustannuksiin sekä edellisistä johtuen rehujen taloudelliseen arvoon.

Nykyisin pidetään rehujen jalostusarvon mittana melkein yksinomaan niiden ry-arvoa. Tosin on jo varhain kiinnitetty huomiota eri rehujen suhteelliseen arvoon ja esitetty vaatimuksia väkevyyden ja valkuaismäärän huomioon ottamiseksi jalostusarvolaskelmissa (4). Mm. Lavr (11), Brinkmann (5) ja Nanneson (15) ovat kysymystä käsitelleet ja esittäneet yksinkertaisia matemaattisia menettelytapoja kuiva-ainesuhteen huomioon ottamiseksi rehujen jalostusarvoa määritettäessä.

NANNESONin mukaan eri rehujen jalostusarvo ry:ä kohden saadaan seuraavista kaavoista:

$$
\begin{aligned}
& \qquad t=\frac{k-r}{r-v}, \text { jossa } \\
& \text { 1) } \\
& t=\text { ry:ä kohden tarvittava väkirehuyksikkömäärä, } \\
& v=\text { käytetyn väkirehun täyttävyys, } \\
& r=\text { koko rehuseoksen täyttävyys, } \\
& k=k . o . \text { kotoisrehun täyttävyys. } \\
& \qquad J=R-t(V-R) \text {, jossa } \\
& 2) \\
& J=k . o . \text { kotoisrehun jalostusarvo, } \\
& R=\text { koko rehuseoksen keskimääräinen jalostusarvo, } \\
& V=\text { väkirehun ry-hinta, } \\
& t=\text { ry:ä kohden tarvittava väkirehuyksikkömäärä. }
\end{aligned}
$$

Käyttämällä laskelmassa täyttävyyslukuja alkuperäisten väkevyyslukujen asemesta laskelma tulee hieman yksinkertaisemmaksi kuin NANNESonin esittämässä muodossa. Näin menetellen voidaan edellä olevat laskelmat ratkaista myös graafisesti asettamalla ordinaatta-akselille rehujen hinnat ja abskissa-akselille niiden täyttävyysluvut. Määräämällä koordinaatistossa ne pisteet, jotka osoittavat rehuseoksen keskimääräisen jalostushinnan ja täyttävyyden sekä väkirehuyksikön hinnan ja täyttävyyden, sekä yhdistämällä nämä kaksi pistettä suoralla viivalla voidaan tältä viivalta lukea eri rehujen jalostushinnat.

Vaikka rehujen kuiva-ainemäärän huomioon ottamista jalostusarvolaskelmissa on pidettävä huomattavana edistysaskelena, menetelmä on kuitenkin puutteellinen, koska toinen tärkeä tekijä, valkuaismäärä, jää laskelman ulkopuolelle. Kuiva-ainemäärän yksinomainen huomioon ottaminen johtaa siihen, että rehujen väkevyyden merkitys 
tulee liiaksi vaikuttamaan rehujen arvoon. Sen tähden menetelmää voidaan suositella käytettäväksi ainoastaan edellyttäen, ettei valkuaisrikkailla ja valkuaisköyhillä väkirehuilla olisi sanottavaa hinnaneroa ry:ä kohden laskettuna. Muussa tapauksessa olisi myös valkuaismäärä otettava perustaksi eri rehujen suhteellista arvoa määritettäessä. Kysymystä on käsitelty varsinkin Suomessa $(10,9,12,8)$. NANNESON on "korvikearvoa» (ersättningsvärde) laskiessaan ottanut huomioon myös eri rehujen valkuaismäärän esittäessään, kuinka suurta öljyväkirehujen, rehuviljan ja olkien määrää 100 ry eri rehuja vastaa (16, s. 95-96). Eri rehujen jalostusarvo voidaan määrittää suhteellisen yksinkertaisesti joko käyttämällä kirjoittajan esittämää laskutapaa (12), joka soveltuu normaalisiin hintasuhteisiin, tai laskemalla jalostusarvo erikseen kullekin rehulle yhtälöitä käyttäen.

Edellyttämällä, että oikean täyttävyyden ja valkuaissuhteen saavuttamiseksi olisi kotoisten rehujen täydennykseksi käytettävä vähintään kahta eri väkirehua. joista toinen valkuaisrikasta, voidaan kunkin eri rehun jalostusarvo ry:ä kohden laskea yhtälöistä, jotka voidaan esittää esim. seuraavassa muodossa:

3

$$
\begin{aligned}
& a x+b y+c=r(x+y+1) \\
& a_{1} x+b_{1} y+c_{1}=r_{1}(x+y+1)
\end{aligned} \text {, joissa }
$$

$\mathrm{x}=$ valkuaisrikkaan väkirehun ry-määrä,

$\mathrm{a}=$ " " valkuaismäärä/ry,

$\mathrm{a}_{1}=\quad$ " " täyttävyys,

y $=$ valkuaisköyhän " ry-määrä,

$\mathrm{b}=$ " " valkuaismäärä/ry,

$\mathrm{b}_{1}=\quad$ " täyttävyys,

$\mathrm{c}=$ k.o. kotoisrehun valkuaismäärä/ry,

$\mathrm{c}_{1}=$ " täyttävyys,

$\mathrm{r}=$ koko rehuseoksen valkuaismäärä/ry,

$\mathrm{r}_{1}=$ " " täyttävyys.

4) $\quad \mathrm{J}=\mathrm{R}-\mathrm{x}(\mathrm{V}-\mathrm{R})-\mathrm{y}\left(\mathrm{V}_{1}-\mathrm{R}\right)$, jossa

$\mathrm{J}=$ k.o. kotoisrehun jalcstusarvo,

$\mathrm{R}=$ koko rehuseoksen keskimääräinen jalostusarvo,

$\mathrm{V}=$ valkuaisrikkaan väkirehun ry-hinta,

$\mathrm{V}_{1}=$ valkuaisköyhän väkirehun ry-hinta .

Jos lasketaan etukäteen, kuinka suuri on rehujen kuiva-aineylijäämä ja valkuaisylijäämä tai -vajaus ry:ä kohden rehuseoksen kesłimäärään verrattuna, voidaan yhtälöitä käyttää Hannukselan (8) esittämässä muodossa. Tulos on sama kuin edellă esitetyllä tavalla laskettuna. 
Esitetty menetelmä soveltuu käytettäväksi kaikissa olosuhteissa, myös silloin, kun rehujen keskimääräinen jalostusarvo on suurempi kuin ostorehujen ry-hinta. Jos keskimääräinen jalostusarvo on väkirehujen hintaa suurempi ja väkirehuja siis kannattaisi käyttää niin paljon kuin olosuhteet tekevät mahdolliseksi, olisi väkevyys- ja valkuaisnormeissa kuitenkin käytettävä enimmäisarvoja. Laskutapa soveltuu käytettäväksi myös silloin, kun ostoväkirehuja ei käytetä lainkaan, suorittamalla laskelma väkirehujen käypien hintojen perusteella. Kotoisten rehujen arvo tulee silloinkin verratuksi ostoväkirehujen hintoihin.

Edellä esitetyt menetelmät, jotka näennäisestä monimutkaisuudestaan huolimatta voidaan saada suhteellisen yksinkertaisiksi käyttämällä valmiiksi laskettuja aputaulukkoja, kuten HANnUkSELA on esittänyt, yhdistävät NANNESONin »korvikearvo»- ja jalostusarvolaskelmien ominaisuudet. Laskemalla eri rehujen hinnat esitetyllä tavalla rehut tulevat verratuiksi väkirehuihin, vaikkakaan ei niin yksipuolisesti kuin NANNESONin käyttämässä menetelmässä on asian laita.

Yhtälöitä käyttäen on mahdollista ratkaista eri rehujen suhteellinen jalostusarvo siinäkin tapauksessa, että rehujen täydennystarvetta laskettaessa olisi otettava huomioon edellisten lisäksi myös muita tekijöitä. Laskutapa kävisi uusien tekijöiden tähden vastaavasti monimutkaisemmaksi.

\section{Eräitä jalostusarvolaskelman epäkohtia.}

Kun jalostusarvolaskelmaan liittyy useita tuotto- ja kustannuseriä, joiden suuruutta ei voida täsmällisesti määrittää, ei laskelman tuloksiakaan voida pitää muina kuin likimääräisinä arvoina. Kuitenkin suurin osa peruskustannuseristä on sellaisia, joiden voidaan katsoa aiheutuvan karjataloudesta ja joiden suuruus riippuu karjatalouden laajuudesta ja voimaperäisyysasteesta. Tässä suhteessa muodostavat rakennuskustannukset huomattavan ja laskelman tuloksiin häiritsevästi vaikuttavan poikkeuksen, sillä tavanmukaisella tavalla laskettaessa rakennuskustannus riippuu paitsi rakennuksen uudisarvosta myös sen iästä. Rakennuskustannus ei siten ole samassa suhteessa karjatalouden tuotantoedellytyksiin kuin muut kustannuserät. Kun rakennusten korkovaatimus lasketaan nykyarvosta, korkokustannus muodostuu sitä suuremmaksi, mitä suurempi on rakennuksen uudisarvo ja mitä vähemmän se on tullut kuoletetuksi. Näin ollen karja- 
talouden antama tulos muodostuu muuten samanlaisissa olosuhteissa sitä edullisemmaksi, mitä enemmän navettarakennuksen uudisarvosta on kuoletettu. Mikäli rehuille lasketaan jalostusarvo, jossa myös rakennuskustannus on otettu huomioon, olisi laskelma muutettava sellaiseksi, ettei rakennuksen erilainen korkokustannus vaikuttaisi lopputulokseen. Esimerkkinä korkokustannuksen vaihteluista yksityisillä tiloilla voidaan mainita ANNILAn julkaisemat tulokset, joissa rakennuspääoman korko on ollut 18-165 mk lypsylehmää kohden vuodessa (2, liite 1).

Rakennuspääoman korkokustannuksen häiritsevä vaikutus voidaan saada eliminoiduksi käyttämällä rakennuskustannusten vuotuista suuruutta laskettaessa ns. anmiteettia, jolla tarkoitetaan kuoletuksen ja korkokustannuksen summaa siten laskettuna, että niiden yhteissumma pysyy vuosittain muuttumattomana. Uudella rakennuksella on pääosa vuotuismaksusta korkokustannusta, kun taas rakennuksen vanhetessa yhä suurempi osa vuotuismaksusta on rakennuspääoman kuoletusta.

Annuiteetti voidaan laskea seuraavasta kaavasta:

5)

$$
\mathrm{a}=\frac{\mathrm{K} \cdot 1.0 \mathrm{p}^{\mathrm{n}} \cdot 0.0 \mathrm{p}}{1.0 \mathrm{p}^{\mathrm{n}}-1}, \text { jossa }
$$

$\mathrm{K}=$ rakennuksen uudisarvo,

$\mathrm{p}=$ korkoprosentti,

$\mathrm{n}=$ rakennuksen kestävyysaika.

Toisena mahdollisuutena on laskea jalostusarvolaskelmissa rakennuspääoman korko puolelle rakennuksen uudisarvosta, jolloin korkokustannus pysyisi muuttumattomana rakennuksen koko kestävyysajan. Kolmantena mahdollisuutena on vihdoin siirtyä käyttämään nettojalostusarvolaskelman sijasta bruttojalostusarvolaskelmaa. Annuiteetti on matemaattisesti oikeampi kuin rakennuksen keskimääräisen korkokustannuksen käyttäminen, joka sitä vastoin on erittäin yksinkertainen käytäntöön sovellettavaksi. Kolmas vaihtoehto ei ole edellisiin verrattavissa, sillä se edellyttäisi jalostusarvolaskelman perusteiden muuttamista.

Toisena tekijänä, joka vaikuttaa häiritsevästi jalostusarvolaskelman tuloksiin, on siitoseläinten myynti, joka saattaa aiheuttaa, ettei lypsykarjalle jäisi lainkaan uudistuskustannusta (1, s. 31). Vertailukelpoisten tulosten saavuttamiseksi menetellään usein siten, että siitoseläinten myynnistä saatu ylihinta pidetään tavallisen jalostus- 
arvolaskelman ulkopuolella. Näin on menetelty mm. L. S. K:n kirjanpitotoimistossa ja Hämeen-Satakunnan maanviljelysșeuran kirjanpitotoimistossa.

Kolmantena jalostusarvolaskelman lopputulokseen ja tulosten vaikuttavana tekijänä on tässä yhteydessä esitettävä jalostushinnaksi jäävän erän suhde karjatalouden kokonaistuottoon sekä jalostusarvolaskelman kohteena olevan rehumäärän suhde tilalla käytettävissä olevaan rehumäärään.

Jalostusarvolaskelma on siinä suhteessa verrattavissa moniin muihin maatalouden kannattavuuslaskelmiin, että tietty kustannuserä jätetään tuntemattomaksi ja laskelman tulos osoittaa, kuinka suuri osa kokonaistuotosta jää tämän tekijän osuudeksi. Niinpä puhdas tuotto osoittaa sitä osaa tuotosta, joka jää pääomien koroksi. Tuloksen arvo riippuu olennaisesti siitä, kuinka suuri merkitys tuntemattomaksi jätettävällä kustannustekijällä on kustannusten kokonaismäärässä. Karjatalouden taloudellista tulosta laskettaessa olisi myös jätettävä tuntemattomaksi se tekijä, jonka osuus on mahdollisimman suuri muihin kustannuseriin verrattuna. Tällainen tekijä on rehukustannus. Epäedullisissa olosuhteissa saattaa perusrehun jalostushinta jäädä mitättömän pieneksi kokonaistuottoon verrattuna. Samanaikaisesti on kuitenkin laskelmaan sisällytetty täysimääräisinä kotoisten väkirehujen hinta, kaikkien pääomien korot, korvaus johtotyöstä ja osuus maatalouden yleiskustannuksista. Korkokustannusten osuus yksinään saattaa olla yli $10 \%$ karjatalouden tuotosta (19, s. 111). Tällaisissa tapauksissa ei jalostusarvolaskelman tulosta voida pitää oikeaan osuvana kannattavuuden mittapuuna, sillä se asettaa perusrehun aiheettoman huonoon asemaan kotoisiin väkirehuihin ja muihin tuotannon tekijöihin verrattuna. Laskelman tuloksia ei myöskään voida käyttää kasvinviljelystä koskevien kannattavuuskysymysten selvittelyyn.

Edellä esitettyyn liittyy jo aikaisemmin kosketeltu kysymys siitä, lasketaanko jalostusarvo kaikille kotoisille rehuille vai ainoastaan perusrehulle. Ottamalla huomioon, että perusrehun osuus yksityisiltä tiloilta julkaistujen tulosten perusteella on voinut olla alle $52 \%$ lypsykarjan käyttämästä rehuyksikkömäärästä $(19$, s. 110) ja perusrehu on voinut jäädä kokonaan vaille jalostushintaa, on tämäkin seikka puoltamassa jalostuslaskelman saattamista laajemmalle pohjalle siten, että se tulisi koskemaan kaikkia kotoisia rehuja.

Vaikeammin on ratkaistavissa jalostusarvolaskelman kohteena olevan rehumäärän ja tilalla käytettävissä olevan rehumäärän keski- 
näisen suhteen vaikutus jalostushintaan, koska tästä kysymyksestä ei liene suoritettu minkäänlaisia tutkimuksia. Jos karjatalous perustuu hyvin huomattavalta osalta ostettujen ja kotoisten väkirehujen käyttöön, huonommat heinät ja kevätviljan oljet jätetään karjalle syöttämättä, puhumattakaan syysviljan oljista, heikommat laitumet jätetään käyttämättä jne., voidaan perusrehun jalostushinnaksi saada näennäisesti hyvinkin edullista tulosta osoittavia lukuja. Tällaisilla tuloksilla ei kuitenkaan voida katsoa olevan arvoa karjatalouden kannattavuuden osoittajana, sillä rehujen jalostushinta kokonaisuudessaan saattaa jäädä varsin vaatimattomaksi käytettävissä oleviin mahdollisuuksiin verrattuna. Jalostusarvolaskelma on oikeutettu ainoastaan silloin, kun karjatalous on oikeassa suhteessa jalostettavana olevaan rehumäärään, laitumien tuotto mukaan luettuna, ja ne rehut, joille jalostusarvo lasketaan, muodostavat karjalle käytettävien rehujen pääosan. Se karjamäärä, tuotantosuunta tai voimaperäisyysaste, jolla saadaan suurin kokonaishinta kaikille käytettävissä oleville rehuille, on taloudelliselta kannalta edullisin riippumatta siitä, kuinka korkeaksi jalostushinta ry:ä kohden muodostuu.

\section{Jalostusarvolaskelman tulosten käytöstä karjatalouden ja kasvinvilje- lyksen kannattavuuden määrittämisessä.}

Jalostusarvolaskelman tuloksia, mikäli ne on saavutettu kestävillä perusteilla, voidaan maataloutta koskevissa kannattavuuslaskelmissa ja taloudellisissa arvioissa käyttää useihin eri tarkoituksiin jopa siinä määrin, että rehuista saadun jalostushinnan suuruutta voidaan pitää maatalouden keskeisimpänä kannattavuuskysymykşenä. Kun jalostusarvolaskelmissa edellä esitetyn mukaisesti voidaan käyttää useita eri menetelmiä, on tuloksilla myös erilainen käyttöarvo ja soveltamismahdollisuus. Tavallisesti ei kuitenkaan tehdä riittävää eroa eri laskelmamenetelmien antamien tulosten välillä, mistä johtuu, että jalostusarvolaskelman tuloksia näkee usein käytettävän harhaanjohtavalla tavalla.

Sekä brutto- että nettojalostusarvolaskelmilla on ensiksikin huomattava merkitys nautakarjatalouden kannattavuuden määrittämisessä. Samoilla perusteilla ja samanlaisissa olosuhteissa saadut tulokset ovat toisiinsa verrattavissa karjatalouden suhteellisen kannattavuuden osoittajina. Jalostushintoja voidaan verrata toisiinsa samalla tilalla eri vuosina tai eri tilojen kesken. Paitsi ry-määrää kohden voi- 
daan jalostusarvo laskea muitakin tekijöitä, esim. lypsylehmien lukumäärää tai tuotettua maitomäärää kohden, jolloin saadut suhdeluvut kuvastavat karjatalouden antamaa tulosta eri puolilta katsottuna.

Jalostusarvolaskelman tuloksia arvosteltaessa niitä usein verrataan rehujen myyntihintoihin tai tuotantokustannushintoihin. Vertailua tehtäessä ei aina oteta huomioon menettelytapaa, jolla jalostusarvolaskelman tulos on saatu. Jos tilalla on käynnissä oleva karjatalous, johon sidotut pääoma- ym. kustannukset joka tapauksessa rasittavat tilaa, nettojalostushinnan vertaileminen myyntihintaan antaa väärän kuvan rehujen erilaisten käyttömahdollisuuksien kannattavuudesta. Kun jokin määrä rehuja myydään jalostushintaa kalliimpaan hintaan, on otettava huomioon, että karjatalouden peruskustannukseen on luettu myös pääomien korkovaatimus, karjatalousrakennusten kuoletus ja kunnossapitokustannus, johtotyön arvo ja osuus yleiskustannuksista, joista ei rehuja suoraan myytäessä saada korvausta. Edellä esitettiin näiden summien keskimääräinen suuruus ja suhde karjatalouden tuottoon ja peruskustannuksen suuruuteen. Myyntihintaa ei siten voida verrata rehujen nettojalostushintaan, vaan bruttojalostushintaan.

Toinen on asian laita, jos tilalle suunnitellaan perustettavaksi hyötykarjataloutta, jota tilalla ei ennestään ole, tai karjataloutta aiotaan tuntuvasti laajentaa. Silloin muodostuu uusia kustannuseriä, jotka eivät ennestään rasita tilaa. Ennakkolaskelmissa on tällaisissa tapauksissa käytettävä nettojalostusarvoa. Laskelmia tehtäessä on kuitenkin otettava huomioon käytettävissä olevin edellytyksin saatava kokonaistulos, joten ry:n jalostushinta myyntihintaan verrattuna ei ole riittävä taloustuloksen mitta.

Kun rehujen tuotantokustannuslaskelmissa on otettu huiomioon kaikki kustannukset, on nettojalostusarvo niihin verrattavissa. Sitä vastoin ei bruttojalostusarvoa voida missään tapauksessa rinnastaa peltoviljelystuotteiden suoranaisia viljelyskustannuksia osoittaviin lukuihin, joissa pääoma- ja yleiskustannuksia ei ole otettu huomioon, koska näiden kustannusten jättäminen laskelman ulkopuolelle vähentää kustannuksia tuoteyksikköä kohden, mutta lisää rehuiksi käytettyjen tuotteiden jalostushintaa.

Jalostushinta soveltuu myös useiden karjatalouden laajuutta ja järjestämistä koskevien kysymysten ratkaisemiseen. NANNESON (17) on verrattain laajasti käsitellyt jalostushinnan vaikutusta karjatalouden järjestelyyn. Jalostushinnan pohjalla on ratkaistavissa karjatalouden laajuus ja tuotantointensiteettiaste sekä erityisesti osto- 
väkirehujen käytön kannattavuus. Mitään edellä esitettyä kysymystä ei tosin voida ratkaista kuten matemaattista tehtävää, vaan ainoastaan vertaamalla eri mahdollisuuksia toisiinsa tai tutkimalla yhden tekijän muuttumista edellyttäen muiden tekijöiden pysyvän muuttumattomina.

Lypsykarjan maksamaa jalostushintaa voidaan käyttää rajoitetussa määrin muiden eläinryhmien kannattavuuskysymysten arvostelemisessa siten, että lypsykarjan maksamista jalostushinnoista saadaan perusta muiden eläinryhmien käyttämien markkinattomien rehujen hinnoittamiseen. On kuitenkin huomattava, että tarkoitukseen voidaan käyttää ainoastaan yleistä tasoa osoittavia, lähellä keskimäärää olevia jalostushintoja, koska lypsykarjatalouden parempi tai huonompi tulos saattaisi yksityistapauksissa vaikuttaa ratkaisevasti muiden kotieläinryhmien antamaan taloudelliseen tulokseen. Eläinryhmille, jotka pääasiallisena rehunaan käyttävät kotoisia rehuja, kuten lampaille ja nuorelle karjalle, voidaan laatia oma jalostusarvolaskelmansa. Jälkimmäisessä tapauksessa ei saada selville nuoren karjan kasvatuskustannuksia, vaan lypsykarjaan siirtyvät eläimet on hinnoitettava käypien hintojen mukaan. Käytettäessä jalostushintoja muiden kotieläinten käyttämien rehujen hinnoitteluun on käytettävä nettojalostushintoja. Bruttojalostushinnat eivät tarkoitukseen sovellu varsinkaan siinä tapauksessa, että muiden eläinryhmien kustannuslaskelmat olisi laadittu ottamatta mukaan pääomaja yleiskustannuksia, koska suhde on sama kuin peltokasvien tuotantokustannuslaskelmissa.

Jalostushintojen vertailu tuotantokustannushintoihin viittasi mahdollisuuteen käyttää jalostusarvolaskelman tuloksia myös peltoviljelyksen kannattavuuskysymysten selvittelyyn. Kun suurin osa satotuloksesta on jalostettava kotieläinten välityksellä, on jalostusarvolaskelman tulosten käyttäminen välttämätön edellytys eri viljelyskasvien välisten kannattavuussuhteiden selvittämiseksi. NANNESON (17, s. 99-108) käyttää tähän tarkoitukseen kahta eri menetelmää riippuen siitä, käytetäänkö arvioitavana oleva lisäsato ensi sijassa ostorehujen korvaamiseen rehuvolyymin pysyessä muuttumattomana vai rehumäärän lisäämiseen, jolloin tulee kysymykseen joko eläinmäärän lisääminen tai eläintä kohden käytettävän rehumäärän lisääminen. Edellisessä tapauksessa NANnEson laskee rehuille »korvikearvon» väkirehujen hintojen perusteella ja jälkimmäisessä jalostusarvon. Edellinen on saatu laskemalla, minkälaista määrää öljyväkirehuja, rehuviljaa ja olkia (O-, F- ja H-rehuja) vastaa 
100 ry:ä k.o. rehua. Valmiiksi lasketusta taulukosta nähdään eri rehujen "väkirehuarvo", jolloin väkirehujen hintojen perusteella voidaan laskea eri rehujen raha-arvo.

Tämän kirjoittaja ei voi pitää, kuten aikaisemmin on mainittu, NANNESONin menettelytapaa onnistuneena, sillä sadon lisäyksen jakaminen kahteen toisistaan erotettuun käyttötarkoitukseen tuntuu keinotekoiselta, koska useimmiten tulevat molemmat mahdollisuudet kysymykseen. Myös on kysymyksenalaista, onko oikein verrata lisäsatoa ainoastaan ostoväkirehujen hintaan jättämällä oljilla korvattava osa rehujen arvosta huomioon ottamatta. Huomattavana etuna "väkirehuarvojen» käytöllä on siinä, että eri rehujen arvo voidaan määrittää erittäin yksinkertaisesti valmiiksi laskettujen taulukoiden ja ostoväkirehun hintojen perusteella. Kirjoittajan käsityksen mukaan molempien arvonmääritystapojen edut voidaan yhdistää käyttämällä yksinomaan jalostusarvolaskelmaa, jossa eri rehujen arvo määritetään niiden väkevyyden ja valkuaismäärän perusteella.

Paitsi erikseen karjatalouden ja peltoviljelyksen kannattavuuskysymysten selvittelyssä voidaan jalostusarvolaskelman tuloksia käyttää menestyksellisesti näiden molempien tuotannonalojen antaman tuloksen osoittamiseen samanaikaisesti. Käytettäessä jalostushintaa karjatalouden kannattavuuden mittapuuna jää laskelman ulkopuolelle sen seikan merkitys, minkälainen on saadun kokonaistuloksen suhde talouden kokonaisuuteen. Kun nautakarja on peltoviljelystuotteiden pääasiallisin jalostaja, onkin koetettu pyrkiä osoittamaan karjatalouden kannattavuus siten, että laskelma liittyisi läheisesti myös peltoviljelyksen kannattavuustekijöihin. Näin on johduttu ajatukseen laskea jalostushinta pinta-alayksikköä kohden, jolloin saatu tulos yhdistää sekä peltoviljelyksen että karjatalouden tuloksen. Ensimmäisenä lienee karjatalouslaskelmien yhdistämistä peltoviljelykseen käsitellyt WoERMAnN (20, s. 60). Kun eri viljelyskasvien ala voi vaihdella laajoissa rajoissa, on epäilemättä tarkoituksenmukaista ottaa jalostushintalaskelman pohjaksi ainoastaan rehunviljelyksellä oleva viljelyspinta-ala. Tätä menetelmää on myös kirjoittaja käyttänyt laatimissaan jalostusarvolaskelmaesimerkeissä (13, s. 115), jolloin on otettu huomioon rehunviljelyksessä ollut pinta-ala sekä lisäksi laidunrehusta saatu kokonaishinta. Samoihin päämääriin viittaa karjantarkastuskirjanpidon laskelmiin v. 1944 sisällytetty tilasto, jossa on esitetty laskettavaksi tuotetun maidon ja rasvan määrä sekä muunnettua viljelysalaa että muunnettua rehunviljelysalaa kohden. Niitty ja raivattu laidun muunnetaan pellon arvoiseksi 
siten, että kaksi hehtaaria näitä tiluslajeja vastaa yhtä hehtaaria peltoa. Jalostusarvolaskelmia ja niiden soveltamista käytäntöön olisi tässä mielessä edelleen kehitettävä.

Kaikissa niissä tapauksissa, joissa voidaan verrata jalostusarvolaskelman tulosta samoilla perusteilla laskettuihin tuloksiin, voidaan käyttää joko brutto- tai nettojalostusarvoa. Jälkimmäiseen liittyvien suurempien virhemahdollisuuksien tähden olisi bruttojalostusarvo useihin tarkoituksiin käytettynä asetettava etusijalle.

Käsitellessään varastopääoman arvioimiseen liittyviä kysymyksiä on kirjoittaja (14, s. 84-85) esittänyt käsityksensä jalostusarvolaskelman soveltuvuudesta varastojen arvon määrittämiseen. Tekijä on lähtökohtana pitänyt maatalouden puhdastuottolaskelmaa. Kun varastojen lisäys muodostaa osan maatalouden kokonaistuotosta ja tämä lisäys saattaa edustaa eräissä tapauksissa yksinään sitä osaa kokonaistuotosta, joka voidaan käyttää aktiivipääoman koroiksi, seuraa tästä, ettei pääomien korkokustannuksia voida tässä tapauksessa lukea jalostusarvolaskelman kustannuksiin, koska korot tulisivat osalle pääomista lasketuksi kahteen kertaan. Sen tähden on varastojen arvioimisessa käytettävä jalostusarvoja, joita laskettaessa ei pääomien korkokustannusta ole luettu peruskustannukseen. Jalostusarvon käytön suhteen varastojen arvioimisessa on otettava huomioon samat varaukset, jotka esitettiin jalostusarvojen käytön suhteen muiden eläinryhmien tuotantokustannuslaskelmissa. Varastojen arvioimiseen soveltuvat ainoastaan jalostusarvolaskelmien keskimääräiset, yleistä tasoa osoittavat tulokset, koska poikkeuksellisissa olosuhteissa saadun jalostushinnan käyttö johtaisi varastojen arvioinnissa taloudelliselta kannalta kestämättömiin tuloksiin.

\section{Loppukatsaus.}

Artikkelissa on käsitelty lähinnä teoreettiselta kannalta rehujen jalostusarvolaskelmia, niiden merkitystä maatalouden kannattavuuskysymyksissä sekä jalostusarvolaskelmien puutteellisuuksia ja niiden tulosten käyttöä rajoittavia tekijöitä.

Kun suomenkielinen termi korvaushinta ilmaisee rehujen arvon ainoastaan yksipuolisesti karjatalouden kannalta katsottuna, aiheuttaa sekaannusta verrattuna vastaaviin vieraskielisiin termeihin ja suomenkieliseen korvikearvo-termiin, olisi tarkoitukseen paremmin soveltuvaa termiä jalostusarvo käytettävä korvaushinnan asemesta. 
Ajatusyhteydestä riippuen voidaan käyttää myös jalostushintaa merkitsemään rehuista jalostamalla saatua taloudellista tulosta.

Jalostusarvolaskelma olisi pyrittävä laatimaan siten, että tulos osoittaa kaikelle kotoiselle rehulle saadun jalostushinnan. Alempien tuotantokustannustensa perusteella olisi laidunrehun arvoksi ry:ä kohden laskettava puolet kotoisten rehujen keskimääräisestä jalostushinnasta. Muiden rehujen jalostushinta olisi laskettava ry-arvon, valkuaismäärän ja täyttävyyden perusteella.

Karjatalouden ja kasvinviljelyksen kannattavuuskysymysten arvostelemiseen voidaan käyttää joko bruttojalostusarvoa tai nettojalostusarvoa, kuitenkin siten, että ainoastaan samoilla perusteilla laadittujen laskemien tuloksia verrataan toisiinsa. Kun bruttojalostusarvolaskelmaan ei sisälly ns. välillisiä kustannuksia, olisi laskelma suuremman yksinkertaisuutensa ja tulostensa luotettavuuden tähden soveltuvissa kohdin asetettava nettojalostusarvolaskelman edelle. Bruttojalostusarvoja ei voida käyttää rehujen arvioimiseen muiden kotieläinryhmien eikä eri viljelyskasvien tuotantokustannuslaskelmissa. Nettojalostusarvoja ei voida verrata samojen rehujen myyntihintaan ottamatta huomioon, että karjatalouden välilliset kustannukset, jotka sisältyvät nettojalostusarvolaskelman kustannuksiin, on suoritettava rehujen myyntihinnasta. Käytettäessä jalostusarvoja varastojen arvioimiseen ei korkokustannusta voida sisällyttää peruskustannukseen.

Muiden kotieläinryhmien käyttämien rehujen hinnoittamiseen ja varastojen arvioimiseen voidaan käyttää ainoastaan rehujen keskimääräisiä, yleistä tasoa osoittavia jalostusarvoja.

Nettojalostusarvolaskelmissa olisi rakennusten korko ja kuoletus vertailukelpoisten tulosten saavuttamiseksi laskettava joko käyttämällä annuiteettia tai laskettava korkokustannus puoleksi kunkin rakennuksen uudisarvon mukaisesta korkokustannuksesta.

Jalostusarvolaskelmien suurimpana heikkoutena on pidettävä tulosten riippuvaisuutta käytettyjen rehujen laadusta sekä perusrehun (tai kotoisen rehun) määrästä verrattuna karjalle käytettyjen rehujen kokonaismäärään ja tilalla käytettävissä olevien rehujen määrään. Ratkaisevana tekijänä karjatalouden kannattavuutta arvosteltaessa on pidettävä käytettävissä olevista rehuista saatavaa kokonaishintaa. Vertailukelpoisten tulosten saavuttamiseksi olisi rehujen jalostusarvo laskettava muunnettua rehunviljelysalan hehtaaria kohden. 
KIR JALLISUUTTA. - LITERATUR.

(1) Annila, Matri 1932 - L.S.K:n kirjanpitotoimiston tutkimustulokset. Käsittää kirjanpitovuodet $1929-30$ ja $1930-31$. L.S.K:n kirjanpitotoimiston julkaisuja. Vammala, 1932 , s. $1-51$.

(2) —— 1938 — Lypsykarjatalouden peruskustannuksesta ja siihen vaikuttavista tekijöistä. Suomen Maataloustieteellisen Seuran julkaisuja, 39. Helsinki, 1938, s. 1-112 + liitteet I-VI.

(3) —— 1939 — Maatalouden kannattavaisuus- ja kustannuslaskelmia. L.S.K:n kirjanpitotilojen tuloksia kirjanpitovuosilta 1929-37. L.S.K:n kirjanpitotoimiston julkaisuja. Vammala, 1939, s. 1-55.

(4) Borgedal, Paul, Ellilä, K. J., Larsen, O. H., Nanneson, Ludvig 1925 Fördelnings- och värderingsregler vid utvidgad lantbruksbokföring. Nordisk Jordbrugsforskning, 1925. Særtryk. København, 1925, s. 1-16.

(5) Brinkmann, Theodor $1910-$ Zur Theorie des Futterwertes. Fühl. Landw. Zeit., 59, s. $721-752$.

(6) Ehrenberg, Paul 1899 - Die Geldwertsberechnung der Futtermittel. Dissert. Jena, 1899 , s. $1-167+$ Tab. I-II.

(7) Ellılä, K. J. 1930 - Maatalousliikkeen järjestelystä ja liiketuloksista valtion koulutiloilla. Maataloushallituksen tiedonantoja, 200. Helsinki, 1930 , s. $1-27$.

(8) Hannuksela, V. 1930 - Lypsykarjan rehujen jalostusarvolaskelmista. Suomen Laiduntalous, IX, s. 47-80. Vammala, 1937.

(9) JäÄskelärnen, Orva 1934 - Tuorerehukysymyksestä. Suomen Laiduntalous, VI, s. 15-44. Vammala, 1934.

(10) Korpela, E. 1929 — Rehujen jalostusarvon määrääminen. Maataloudellisia päivänkysymyksiä. Agronomisen yhdistyksen yleisiä julkaisuja, III, s. $66-76$. Porvoo, 1929.

(11) Laur, E. 1915 - Zur Bewertung der Futtermittel. Fühl. Landw. Zeit., 64, S. $377-407$.

(12) Mäкı, ANтtı 1937 - Väkevyyden ja valkuaismäärän vaikutuksesta rehujen korvaushintaan. Maataloustieteellinen Aikakauskirja, 9, s. $35-45$

(13) —- 1938 — Laskelmaesimerkkejä. Rurik Pihkala, Maanviljelystalouden alkeet, s. 106-139. Porvoo, 1938.

(14) —— 1943 — Varastopääomasta ja sen suuruussuhteista eräillä etelä-Suomen maatiloilla. Suomen Maataloustieteellisen Seuran julkaisuja, 52. Hämeenlinna 1943 , s. $1-208$.

(15) Nanneson, Ludvig 1927 - Foderskördarnas realisationsvärde. Landmannen 1927. Särtryck. Stockholm, 1927, s. $1-40$.

(16) —— L. 1936 — Jordbruksekonomi för de lägre lantbruksläroverken och för självstudium. 3. omarb. uppl. Stockholm, 1936, s. 1-192.

(17) Nanneson, L., Nilsson, Hualmar, Ytterborn, G. R. 1943 - Jordbruksekonomi för jordsbrukets ungdomsskolor och för självstudium. 5. omarb. uppl. Stockholm, 1943, s. 1-224.

(18) Pinkala, Rurik 1927 - Maatalouden kannattavaisuustutkimuksia HämeenSatakunnan maanviljelysseuran kirjanpitotoimistossa. Vammala, 1927, S. $1-100$. 
(19) Virtanen, K. L. 1933 - Maatalouden ja sen eri tuotantoalojen kannattavaisuus Hämeen-Satakunnan Maanviljelysseuran Kirjanpitotoimiston kirjanpitotulosten perusteella tilikausilta 1. 7. 1926-30. 6. 32. HämeenSatakunnan maanviljelysseuran kirjanpitotoimiston julkaisuja, 3. Kangasala, 1933, s. 1-168.

(20) Woermann, E. 1933 - Die Veredlungswirtschaft. Berlin, 1933, s. I-VIII + $1-240$.

(21) Räkenskapsresultat från svenska jordbruk I-XXIV. (Tilivuodet 1914-1938).

(22) Tutkimuksia Suomen maatalouden kannattavaisuudesta I-XXVII. (Tilivuodet $1912-1939)$.

(23) Undersøgelser over Landbrugets Driftsforhold. Regnskabsresultater fra danske Landbrug III-XXIII. (Tilivuodet 1918-1939).

\title{
REFERAT.
}

UBBE DIE VEREDLUNGSWERTBERECHNUNGEN VON FUTTERMITTELN.

\author{
ANTTI MäKI
}

\section{Institut für Wirtschaftslehre des Landbaus der Universität, Helsinki.}

Im vorstehenden Artikel werden Veredlungswertberechnungen von Futtermitteln, ihre Bedeutung für die Rentabilitätsfragen der Landwirtschaft, wie auch die Mängel der Veredlungswertberechnungen und die auf die Verwendung der Resultate beschränkend wirkenden Faktoren behandelt.

$\mathrm{Da}$ die Veredlungswertermittlung der Futtermittel auf mehrere verschiedene Weisen ausgeführt werden kann, entweder für den ganzen Rindviehbestand oder nur für die Milchkühe, für sämtliche Futtẹrmittel, oder für die sog. nicht marktfähigen Futtermittel, der Wert der Weide kann auf verschiedene Art berechnet werden u.s.w., können nur die Resultate der nach denselben Prinzipien ausgeführten Berechnungen mit einander verglichen werden. Man müsste bestrebt sein, die Veredlungswertberechnung so auszuführen, dass das Ergebnis den Veredlungswert sämtlicher im eigenen Betrieb produzierter Futtermittel angäbe. Da die Produktionskosten der Weidefuttereinheit geringer als die anderer Futtermittel sind, müsste als Wert des Weidefutters die Hälfte des durchschnittlichen Veredlungswertes der im Betrieb erzeugten Futtermittel gerechnet werden. Der' Veredlungswert der übrigen Futtermittel sollte nicht nur auf Grund von Futtereinheiten, sondern durch in betrachtnahme des Eiweissgehalts und der Konzentration der Futtermittel berechnet werden. Das genaueste Ergebnis erhält man, wenn man mit Hilfe von Gleichungen berechnet, wie viel eiweissreiches und eiweissarmes Kraftfutter die verschiedenen Futtermittel als Ergänzung beanspruchen und wenn man vom durchschnittlichen Veredlungswert der Futtermittel den Preiszuschlag der Kraftfuttermittel abzieht.

Zur Beurteilung der Rentabilitätsfragen der Viehzucht und des Pflanzenbaus kann entweder der Bruttoveredlungswert oder Nettoveredlungswert benutzt werden. 
Bei der Berechnung der zuerstgenannten werden keine indirekten Unkosten in Betracht genommen. Weil hierdurch die Bruttoveredlungswertberechnung einfacher ist und die Ergebnisse zuverlässiger als die der Nettoveredlungswertberechnung sind, sollte der Bruttoveredlungswert in solchen Fällen, für die er sich eignet verwendet werden.

Bruttoveredlungswerte können nicht zur Feststellung von Futterwerten bei Produktionskostenberechnungen anderer Haustiere sowie für Produktionskostenberechnungen der Kulturpflanzen benutzt werden. Nettoveredlungswerte kann man nicht mit dem Verkaufspreis der Futtermittel vergleichen, ohne dass die indirekten Unkosten der Viehwirtschaft, die bei den Nettoveredlungswertberechnungen zu den Unkosten gezählt werden, aber vom Verkaufspreis der Futtermittel beglichen werden müssen, inbetracht genommen sind. Werden zur Feststellung des Wertes der Vorräte Veredlungswerte benutzt, so können die Zinsen nicht zu den Unkosten gezählt werden.

Um den Wert der Futtermittel anderer Haustiere festzustellen und die Bewertung der Vorräte durchzuführen, kann man nur die durchschnittlichen, das allgemeine Niveau darstellenden Veredlungswerte der Futtermittel benutzen.

Bei den Nettoveredlungswertberechnungen sollten die Zinsen und die Abschreibung der Bauten, damit vergleichstaugliche Ergebnisse erzielt würden, durch Verwendung einer Annuität oder durch Beiechnung der Zinsen des halben Neuwerts des Baus festgestellt werden.

Als die grösste Schwäche der Veredlungswertberechnungen muss die Abhängigkeit der Ergebnisse von der Art der verwendeten Futtermittel und dem Verhältnis zwischen den, dem Vieh verfutterten eigenen oder nicht marktfähigen Futtermitteln und der totalen fürs Vieh verwendeten Futtermenge, wie auch dem im Betrieb zur Verfügung stehenden Futter, die Weide einbegriffen, betrachtet werden. Bei der Beurteilung der Rentabilität der Viehzucht muss der für die zur Verfügung stehenden Futtermittel erhältliche Totalpreis als ausschlaggebender Faktor angesehen werden. Um vergleichfähige Ergebnisse zu erzielen müsste der Veredlungswert der Futtermitmittel je red. Hektar Futteranbaufläche berechnet werden. 